\title{
Foreign experience in the implementation of PPP projects for the improvement of the Russian model
}

\author{
Inna V. Lazanyuk, Tatyana V. Yakovleva \\ Peoples' Friendship University of Russia (RUDN University) \\ 6 Miklukho-Maklaya St, Moscow, 117198, Russian Federation
}

\begin{abstract}
This article represents a comprehensive analysis of the PPP projects implementation. The goal is to improve the Russian public-private partnership mechanism by exploring foreign practice. It entails specific objectives: to compare the selected countries according to the criteria of a legal framework for PPP implementation, the forms of PPP, the organizational and legal structure for managing these partnerships. The article reveals the interconnection between the priorities of specific industries for PPP implementation as the social and economic development of these countries. In addition, the problems in the Russian PPP model are identified and the ways to eliminate them are presented based on the best foreign practice, both for the mechanism as a whole and concerning a specific area - healthcare.
\end{abstract}

Keywords: PPP, public-private partnership, concession, healthcare, business, infrastructure

\section{Introduction}

In the modern world, every country is focused on the effective management of its infrastructure facilities. PPP allows the government to involve private financial and intellectual resources and finally create profit from mutually beneficial cooperation between the public and private sectors.

Some countries have accumulated a wealth of experience in implementing such projects, which would be useful for other countries, less developed in this industry. In particular, some items can contribute to the development of the Russian PPP model. Thus, the subject of the article is a relationship between the partnership entities during the PPP. The object is PPP as a tool of cooperation between government and business.

The process of implementing PPP projects is a particular issue in the modern economy. The problems include: the effectiveness of the PPP mechanism for improving infrastructure facilities, the selection of a suitable PPP model for project implementation, as well as the impact of factors that connected with the level of PPP development, such as the historical background and economic situation in the state, its goals, objectives and state policy that determines the priorities of PPP development in the country. 


\section{Literature review}

In the international practice PPP mechanism is used to attract private companies for long-term financing and management of a wide range of public infrastructure facilities. According to the research made by the European Investment Bank $^{1}$, in 2019, total cost of PPP projects that passed the financial closing stage was 9.8 billion euros, which is $31 \%$ less than 14.3 billion euros in 2018 . In this connection, the number of PPP transactions fell to 29, compared to 38 in 2018. And this is the lowest number of transactions since 1996. In recent years, we can see that the studies on PPP practice became widespread in academic literature while there is still not enough research in the Russian one. At the same time, some issues on PPP are highly exciting and remarkable because of the opportunity to apply them for the improvement of the domestic PPP model. They include such items as PPP strategic planning development or identifying priority industries for PPP. Investigation of the current situation as well as the PPP trends in the implementation of infrastructure projects are presented in foreign authors (Cui et al., 2018). Moreover, a sufficient number of works are devoted to the issues of PPP mechanism efficiency. In the article called "Public-private partnerships in health care services: Do they outperform public hospitals regarding quality and access? Evidence from Portugal" (Ferreira, Marques, 2020), two Portuguese scientific researchers reveal that the usage of PPP in healthcare helps to increase the efficiency of providing medical services. The article (Comendeiro-Maaløe et al., 2019) aims to provide a detailed analysis discovering that PPPs are superior compared with other mechanisms in terms of its productivity, expenditures, and quality. The study by Thai authors reveals the potential advantages of PPPs. They allow overcoming the main limitations that cannot be done using traditional approaches. But along with it, certain risks lead to additional costs associated with the complexity of PPP partnerships. Successful experience in applying PPPs in different countries has shown that the state can use services of a qualified private sector for effective implementation of development programs that eliminate the weaknesses of the public sector (AzamiAghdash et al., 2020; Sehgal, Dubey, 2019). Such studies as (Matos, Gonçalves, 2020; Palcic et al., 2019) are the matter of the most interest for the present study: they are devoted to the assessment of transparency and controllability of reducing possible losses related to the decision-making process and inefficient allocation of public resources.

\section{Methodology of study}

The comprehensive analysis of the PPP mechanism includes four considered criteria of PPP: legal framework, the primary PPP forms, the organizational structure of management, and the industrial structure of PPP projects over the past five years in the countries of Europe, Asia, and North America, in Australia and Russia.

The analysis of the PPP legal framework in different countries is presented in Table 1. This first criterion shows that in developed countries: the UK, the USA,

${ }^{1}$ Market Update. Review of the European PPP Market in 2019 / European Investment Bank. 2019. URL: https://www.eib.org/attachments/epec/epec_market_update_2019_en.pdf (accessed: 30.05.2020). 
Canada, and Australia, where the case-law system is used, there is no specific law on PPP. In France and Germany, there is a special law and in these countries, it is used subordinate legislation on PPP in different sectors. For example, in France it covers healthcare, in Germany - the transport sector. Most of the other European countries, like the Netherlands, Czech Republic, and Turkey use concession law ${ }^{2}$. Contracts law is used in the UK, Spain, and Canada. In Asian countries: Japan applies the law on PFI, and China is currently developing a law on PPP.

Table 1

PPP legal framework and main forms of analysis

\begin{tabular}{|c|c|c|}
\hline Country & Legislation on PPP & PPP main forms \\
\hline UK & No PPP law; provisions on government contracts & PFI, corporatization, outsourcing state functions \\
\hline France & Law “On PPP”; industry PPP law in healthcare & The concession agreement, agreement on PPP \\
\hline Germany & $\begin{array}{l}\text { Law "On PPP"; industry PPP laws in trans- } \\
\text { port sphere }\end{array}$ & $\begin{array}{l}\text { Leasing, concession, company owner and } \\
\text { the acquirer model }\end{array}$ \\
\hline $\begin{array}{l}\text { Czech } \\
\text { Republic }\end{array}$ & Law "On concessions" & $\begin{array}{l}\text { PPP contract, life cycle contract, lease agree- } \\
\text { ment, concession }\end{array}$ \\
\hline Hungary & $\begin{array}{l}\text { Law "On state purchases"; EU directives on } \\
\text { concession contracts and public services }\end{array}$ & $\begin{array}{l}\text { The PPP contract, life cycle contract, mana- } \\
\text { gement contract, the concession agreement }\end{array}$ \\
\hline Turkey & $\begin{array}{l}\text { Law "On concessions", "Built, lease, trans- } \\
\text { fer" law }\end{array}$ & Concession agreement, agreement rent, leasing \\
\hline India & "Law on infrastructure development" & $\begin{array}{l}\text { The management contract, the concession } \\
\text { agreement }\end{array}$ \\
\hline Japan & Law “On PFI” & The concession agreement, PFI \\
\hline China & $\begin{array}{l}\text { Law "On public procurement"; measures for } \\
\text { concessions administration }\end{array}$ & $\begin{array}{l}\text { Leasing, concession agreement, mixed eco- } \\
\text { nomic companies }\end{array}$ \\
\hline Canada & Law "On contracts"; regional legislation acts & $\begin{array}{l}\text { Concession, PPP contract, lease contract, life } \\
\text { cycle contract }\end{array}$ \\
\hline USA & $\begin{array}{l}\text { PPP recommendations; regional legislation } \\
\text { acts }\end{array}$ & $\begin{array}{l}\text { The concession agreement, lease contract, } \\
\text { life cycle contract }\end{array}$ \\
\hline Australia & National policy and guidelines for PPP & The concession agreement, life cycle contract \\
\hline Russia & Law "On concessions", the law "On PPP" & $\begin{array}{l}\text { PPP agreement, concession, investment and } \\
\text { lease agreement, life cycle contract }\end{array}$ \\
\hline
\end{tabular}

Source: compiled by the authors according to PPP Legal Resource Center. World Bank Group. URL: https://ppp.worldbank.org/public-private-partnership/legislation-regulation/laws/ppp-and-concession-laws (accessed: 20.05.2020).

Talking about the Russian legal framework, the national law "On concession agreements" was passed in $2005^{3}$. And the law "On PPP” was passed in Saint

${ }^{2}$ Directive 2014/23/EU of the European Parliament and of the Council of 26 February 2014 on the award of concession contracts. URL: https://eur-lex.europa.eu/legal-content/EN/TXT/PDF/ ?uri=CELEX:32014L0023\&from=EN (accessed: 11.04.2020).

${ }^{3}$ Federal Law of the Russian Federation of July 21, 2005, No. 115-FZ "On concession agreements”. URL: http://www.consultant.ru/document/cons_doc_LAW_54572/(accessed: 12.04.2020). 
Petersburg in $2006^{4}$. During the next ten years, such laws were issued at the regional level and eventually federal law on PPP was passed only in 2015 to set standards for the PPP activities ${ }^{5}$. However, it didn't take into account all the features of laws passed at the regional level. So it brings contradictions while implementing the projects. Also, in Russia, there are no unique subordinate legislation acts by sectors.

The second criterion of the analysis shows that the most used forms of PPP are concession agreements, service contracts, PPP agreements, and lease agreements. The supporting information is presented in Table 1, as well.

The third criterion reflected the structure of PPP management. In most cases, it is presented as a centralized model and the operator model.

The centralized model implies that the government performs the coordination of PPP activities. The procedures of technical, finance assessment and project selection are performed by the relevant ministry, e.g. Ministry of Finance, Ministry of Economy, or Ministry of Transport. Countries use this model: Japan, China, the Czech Republic, and Russia.

The operator model assumes that earlier described functions are shared between the private and public sectors. In this way, the representatives of the ministries of the different areas are united in a separate executive body, an Interdepartmental Commission. There is a separate legal entity, a half state-owned company, or an authorized PPP body that conducts a technical evaluation of the projects to select them. This organization has divisions across the country's regions and coordinates PPP activities in all sectors. Countries with more wealth experience in PPP, such as the UK, France, Germany, India, and Canada, use this model.

\section{Industry structure analysis of PPP projects}

The "Industry structure" criterion includes analysis of PPP projects implemented over the past five years in the reviewed countries. The results are presented in Figure 1, called "Industry structure of PPP projects in the countries of the world".

Among the countries of Central Europe: the UK, France, and Germany the most significant number of projects implemented in the education sector. Other countries have more projects in the transport industry. This trend reflects the social and economic development of these countries and their policies. Highly developed countries implement PPP in the educational and health sectors, focusing on developing innovation in the country and improving the quality of life of the population. European countries with the transition economy are implementing projects which include the construction of roads, railways, and airports, due to the lower economic development and lack of budget funds for infrastructure. Thus, in the Czech Republic, Romania, and Moldova, PPP activities are focused on the transport and

${ }^{4}$ Law of Saint Petersburg from December 20, 2006, No. 627-100 "On participation of Saint Petersburg in public-private partnerships". URL: http:/old.economy.gov.ru/minec/activity/sections/ privgovpartnerdev/doc20061225_01 (accessed: 12.04.2020).

${ }^{5}$ Federal Law of the Russian Federation of July 13, 2015, No. 224-FZ "On the publicprivate partnership, municipal-private partnership in the Russian Federation and amendments to certain legislative acts of the Russian Federation". URL: http://www.consultant.ru/document/cons doc_LAW_182660/(accessed: 14.04.2020). 
engineering fields, while PPP in the social sphere not developed. The exception is Hungary, which has a high number of projects in the education sector. Notable, that Turkey focuses its PPP activities only in three sectors. More than 65\% of the total number of projects is contributed to the healthcare sector, which shows high results in this area. Spain also implements PPP projects by prioritizing the healthcare sector as well as the transport and energy sectors.

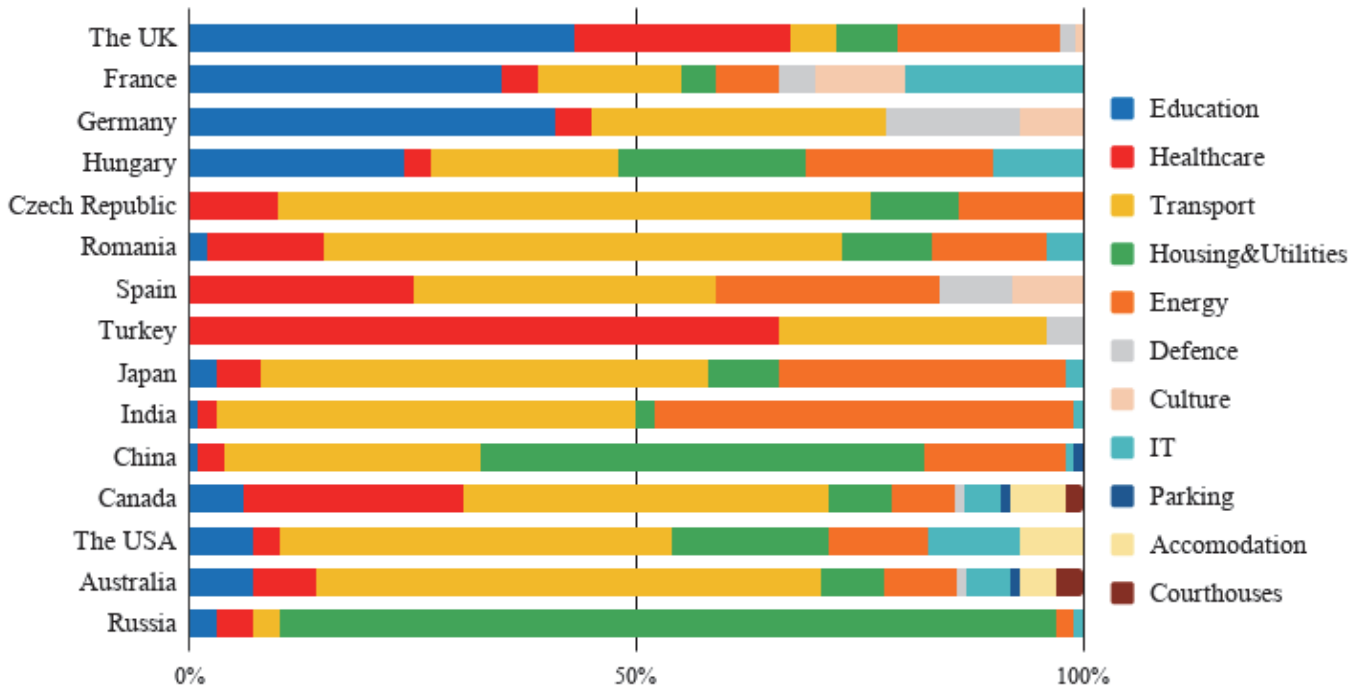

Figure 1. Industry structure of PPP projects in the countries of the world

Source: compiled by the authors according to the EPIC Data Portal. The total value of European PPP projects by sector. A number of European PPP projects by sector. URL: https://data.eib.org/epec (accessed: 14.04.2020); IJGlobal Project Finance and Infrastructure Journal. URL: http://www.ijglobal.com (accessed: 16.04.2020); InfraPPP. Infrastructure Finance \& Investment. URL: https://www.infrapppworld.com/countries/ (accessed: 20.04.2020); ROSINFO. Database of infrastructure projects. URL: https://rosinfra.ru/ (accessed: 25.04.2020).

In Asian countries, we can see that the most common industries for implementation of PPP are transport, energy, housing and utility industries. In the housing and utilities sector, China implements almost $50 \%$ of the total number of projects, Japan - more than $10 \%$. India implements $45 \%$ of the total amount of projects in the energy sector, Japan $-30 \%$, and China $-16 \%$. A half of all projects is implemented in the transport sector as the result of limited budget funds accompanied by the permanently growing needs of the population. Also notable is that China and India provide financial support for low-income developing countries in launching PPP projects.

The industry structure of Canada, the USA, and Australia is highly diversified. These countries try to involve most of the areas in PPP projects. Along with the numerous projects in transport, prevail the projects in the social sphere. For Canada, it is the health sector for the USA - the rest of the projects are divided equally among themselves, for Australia - both educational and health sectors. Projects have also implemented in atypical PPP sectors, such as the construction of ships and parking lots.

The industry structure of PPP projects in Russia reflects the predominance of projects in the housing and utilities sector. Until 2015, the industry structure looked differently from now, because the share of projects in this sphere was less. 
The percentage of industries has changed since 2015. This sector began to occupy more than $80 \%$ of the total number of projects in 2017 . This change was spontaneous, and this sphere still not defined as a priority for implementing PPP projects by policy or strategic document. At this stage, the government also should be motivated in the development of other areas using PPP.

\section{Results: identified problems and steps for improvement of the Russian PPP mechanism}

Having studied the different features of PPP implementation, Russia can benefit from some of them to develop its model. So, the identified problems and positions for the improvement could be united in the following categories.

The first group unites the problems of the legal framework of implementation PPP projects. For contradictions of Russian federal and municipal legislation, it is proposed to develop amendments to national PPP's law, by the requirements of regional authorities. Also, it is advisable to fix the risks of the parties involved in the legislative document's projects, taking as an example of French legislation. In addition, it is proposed to pass subordinate legislation on PPP in different sectors, and it will make the process clear and attractable for the private partners.

The second group unites problems related to the strategic planning of PPP in Russia. In most cases, PPP agreements are concluded for a long-term period. So, the strategic plan of PPPs going to be implemented is a crucial document in this area. To solve this problem, Russia can benefit from Australia or the UK's experience, which use long-term plans for about 30 years in their PPP activities. Turkey's experience shows that focusing on a priority sector from a strategic perspective has yielded high results in the development of the country's health sector. In 5 years, it has moved from 43 to 26 places in countries' ranking by the level of health care.

Another solution could be to implement individual infrastructure sufficiency assessment in Russian regions to identify which facilities residents need most of all and after make a plan of PPP that the government can reach with private partners. Such a tool applied in many developed countries, e.g., in the UK. This assessment helps to create a plan of PPPs needed in the particular region and, as a consequence, to allocate budget properly. And the final problem is the low level of private partners' involvement in PPP projects in the social sphere, the solution to which would be presented below in the article.

\section{Implementation of a strategy for improvement of Russian PPP mechanism}

Further are proposed responsible parties to implement the measures mentioned above. An authorized PPP body could perform coordination and management functions with its branches in Russian regions, which would be focused on earlier identified problems. This model is presented on the Figure 2 and it is based on "The operator model", assumes the structure consists of a single national body and the presence of its branches. This PPP organization could be a half-state company and considered as a link between government and business. Currently, the authorized bodies for PPP activities in Russia are public authorities, while private companies provide consulting services. 


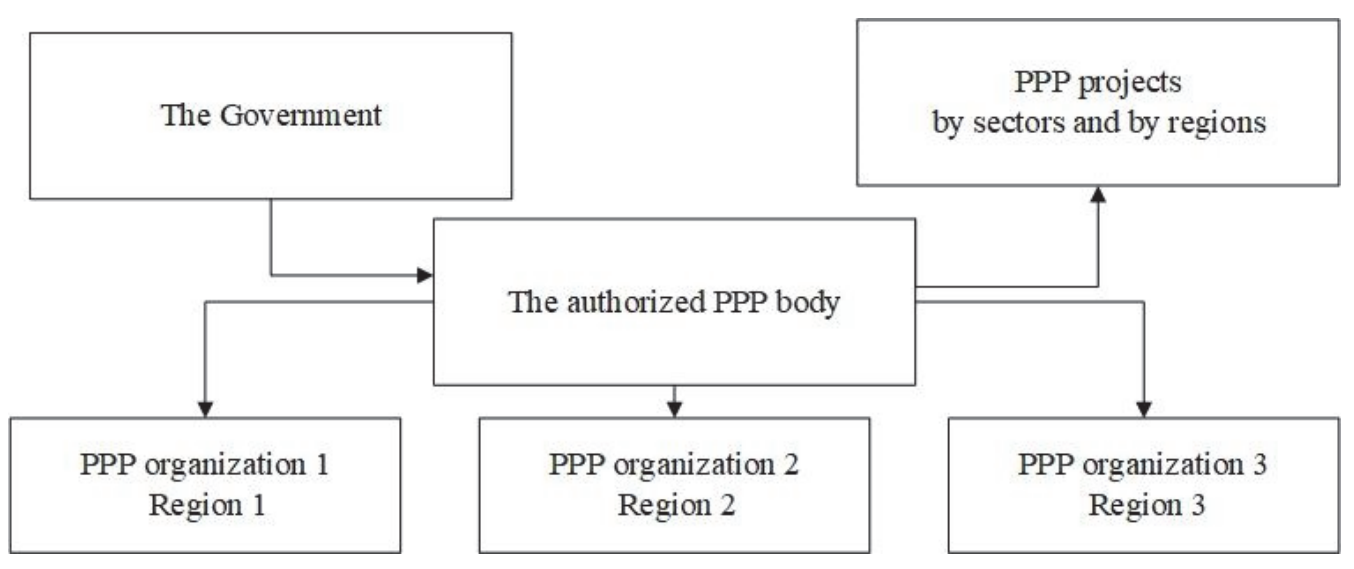

Figure 2. The recommended organizational structure of Russian PPP management

Source: compiled by the authors according to the data revealed in the course of research.

So, in the recommended model, the branches are appointed: to assess the level of infrastructure sufficiency and its conditions in the region; to identify facilities, which are necessary for the residents of the particular region; to identify sectors to conclude contracts and finally make a plan of the concrete objects for PPP. This information should be transmitted to the parent organization, the authorized PPP body, which would be responsible for solving the problems of the legal framework and developing a strategic plan. Also, it would evaluate the performance of the branches by using particular key performance indicators. And as a result, it will encourage regions that show the best results and support branches that do not cope with their PPP activities. Also, branches should raise awareness of potential private sector participants.

\section{PPP in the Russian healthcare system}

The social sector has some features that make it not so attractive for private partners. It is associated with the lack of flexibility in the changing environment and the complexity of introducing innovations. In the healthcare system, we deal with such problems as the reduction of government funding over the past five years by $0,4 \%$, worn-out equipment and equipment failure in $56 \%$ of cases, outdated equipment of laboratory research services operating more than 30 years of service and as the result, decrease in public satisfaction with the services provided. These prerequisites for implementing PPP projects justify the need for using PPP. Table 2 presents three directions which could be developed using this mechanism. The first direction implies using partnerships in the provision of medical services covered by mandatory medical insurance. The second is the development and provision of stationary services at home by the private sector, the third - is the creation of centralized clinical and diagnostic laboratories.

1. Model of commercial concession in the Russian healthcare system. It is advisable to consider the strategy of PPP development in the first direction, in which private clinics would be involved in providing primary health care services for Mandatory Healthcare Insurance (MHI). It implies the involvement of private sector in delivering paid and free medical services under commercial concession. 
This PPP model is based on Design, Built, Operate, Deliver Services but assumes using only part of it. Private partner could operate and deliver services. According to the local realities due to the fact that in 2014 was implemented a program of optimizing hospitals and clinics, many buildings and premises, are unused at the moment. For this reason, as it is presented in Figure 3, it is advisable to lend the infrastructure facilities to private partners and allow them to provide necessary medical services within the framework of PPP projects under a concession agreement.

Table 2

Directions in the Russian healthcare which could develop using PPP

\begin{tabular}{cl}
\hline The trend in the Russian healthcare system & \multicolumn{1}{c}{ Strategy } \\
\hline Mandatory Healthcare Insurance & $\begin{array}{l}\text { 1. Attracting private organizations. } \\
\text { 2. Improving the quality of services provided to the po- } \\
\text { pulation }\end{array}$ \\
\hline Stationary services & $\begin{array}{l}\text { Development and provision of fixed services at home by } \\
\text { the private sector }\end{array}$ \\
\hline Innovative medicine (dialysis, laboratory tests) & $\begin{array}{l}\text { The creation of centralized clinical and diagnostic la- } \\
\text { boratories }\end{array}$ \\
\hline
\end{tabular}

Source: compiled by the authors according to the data revealed in the course of research.

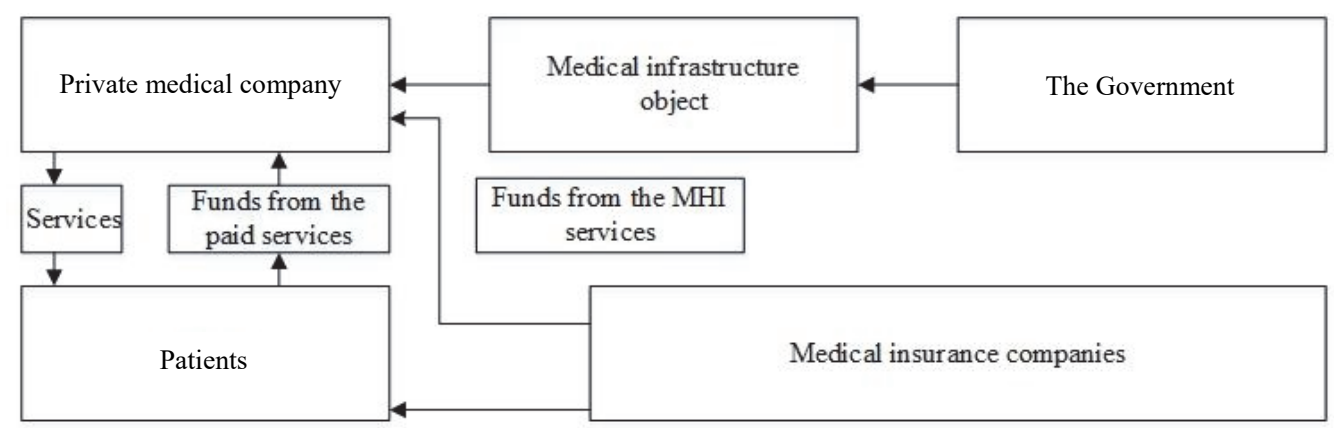

Figure 3. Recommended model of the involvement private sector in delivering paid and free medical services

Source: compiled by the authors according to the data revealed in the course of research.

The state will provide property, while the private partner will use it for delivering both paid and free medical services under the MHI. The company receives revenue from the paid services directly from the patients, while it gets money from other services - from the territorial Fund of Insurance companies. The state retains ownership of the object. A wealth foreign experience on this issue have countries like the UK, Canada, the USA and Asian countries, which implement this model in the context of the health care organization cluster. It involves interaction between all parties using this model and increasing the level of healthcare system in the region.

2. PPP in the sphere of stationary services at home. Implementation of the abovementioned program to optimize hospitals and clinics, budget funds increased. But their absence caused some negative influences on society, presented as the reduction of 55 thousand doctors and 33,8 thousand hospital beds and the increased hospital 
mortality rate in 61 regions. So, it leads to the development of stationary services at home. The involvement of the private sector will contribute to its effective development. An analysis of comparison of prices on services provided by public and private organizations, there were considered private medical centers like "Diagnostics \& Treatment" and "SM-Clinic" and public - State Clinical Hospital No. 29 named after N.E. Bauman. And it was found that patient care is more expensive for the state budget than for the private one. Thus, private medical centers could provide such services as intravenous injection, intramuscular injection, dropper, wound dressing, sampling of analyses, and patient observation for the lower price. In particular, servicing a patient by a public organization is 6240 rubles per day, while for private is 4000 per day. So, in public-private partnership, this difference in budget expenditures could cover the necessary expenditure items in healthcare.

Referring to the foreign experience, in France, for example, within the framework of the PPP program, the private sector operates for providing services in a stationary form on home. One of the major companies involved is "Santé Service HAD", which accompanies hospitalization at home, with the same quality conditions and security, as in the hospital, and provides care and support services for human and medical care.

3. Public-private partnership in the creation of centralized clinical and diagnostic laboratories. The next direction for implementing PPP projects in Russian healthcare is the creation of centralized clinical and diagnostic laboratories. The prerequisites for these partnerships are the obsolete equipment for conducting laboratory tests. It has an impact on the results $-30 \%$ of all researches give false results and $20 \%$ are repeated. So, it is advisory to create a central clinical and diagnostic laboratory in each region equipped with innovative equipment - automatic analyzers.

It will allow avoiding determination of the wrong diagnosis of clients as well as contributing to a lower time frame for obtaining test results and will make available some tests of high complexity. Finally, it will make it possible to detect rare diseases. So, the model of such PPP is presented in Figure 4.

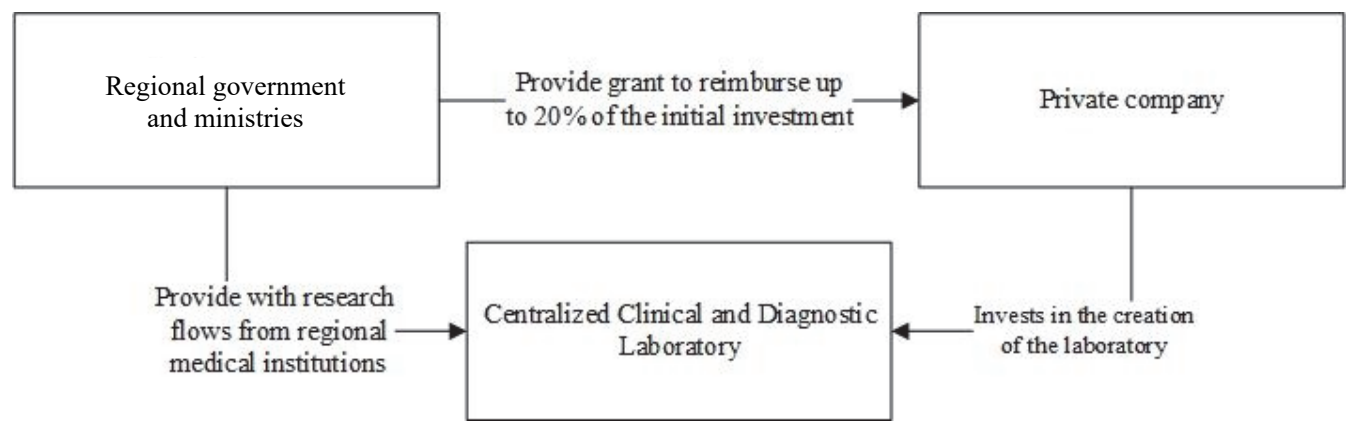

Figure 4. PPP model of the project of creation centralized laboratories

Source: compiled by the author according to the data revealed in the course of research.

The obligations of the parties would be the following. The private partner would be responsible for the project's implementation: he will build or repair the object, purchase the equipment, recruit the staff for the laboratory center, and manage 
the process. The public partner would provide grants to reimburse up to $20 \%$ of the initial investment and provide the center with research flows from regional medical institutions. So this model eventually will develop the healthcare sphere in regions itself.

World Health Organization's specialists propose this model in Russia based on successful foreign experience. It implies that there are one or more centers equipped with the innovative equipment in the region, depending on the number of people where the analyses are delivered, their research carried out using automatic analyzers. This center should take over up to $50 \%$ of all studies conducted in the region, thus replacing the network of outdated laboratories.

\section{Conclusion}

The results of the considered issues lead to the following conclusions.

It was found that each country defines the leading sector for the implementation of PPP projects depending on the goals and priorities of its economy: it is the social sector for developed countries in Europe, transport - for European countries with economy in transition, energy and transportation - for Asian countries. Countries of North America and Australia apply the PPP mechanism in many areas simultaneously. As for Russia, the lead sector in PPP projects is housing and utilities.

Currently, Russia has formed a base for PPP implementation but requires development to reveal its potential. The system's main weakness is the low level of involvement of the private sector and problems because of incomplete legislation and high risks. As a result of the research, the organizational structure for coordinating PPP activities in Russia, with the authorized body and the system of branches, is presented. The model would allow assessing the infrastructure sufficiency in the regions, identifying objects that require modernization and drawing up a PPP plan.

Moreover, the particular model for the concession in providing medical services by the private sector and stationary services is proposed. As well as, it is necessary to use PPP to create the centralized clinical and diagnostic laboratories in Russian regions.

\section{References}

Almarri, K. (2019). Perceptions of the attractive factors for adopting public-private partnerships in the UAE. International Journal of Construction Management, 19(1), 57-64. doi: $10.1080 / 15623599.2017 .1382082$.

Asian Development Bank. (2017, November). Public-Private Partnership Monitor. Retrieved May 30, 2020, from http://www.adb.org/publications/public-private-partnership-monitor

Azami-Aghdash, S., Sadeghi-Bazargani, H., Saadati, M., Mohseni, M., \& Gharaee, H. (2020). Experts' perspectives on the application of public-private partnership policy in prevention of road traffic injuries. Chinese Journal of Traumatology, 23(3), 152-158. https://doi.org/ 10.1016/j.cjtee.2020.03.001

Comendeiro-Maaløe, M., Ridao-López, M., Gorgemans, S., \& Bernal-Delgado, A. (2019). Public-private partnerships in the Spanish National Health System: The reversion of the Alzira model. Health Policy, 123(4), 408-411. https://doi.org/10.1016/j.healthpol. 2019.01.012

Cui, C., Liu, Y., Hope, A., \& Wang, J. (2018). Review of studies on the public-private partnerships (PPP) for infrastructure projects. International Journal of Project Management, 36(5), 773-794. https://doi.org/10.1016/j.ijproman.2018.03.004 
Ferreira, D.C., \& Marques, R.C. (in press). Public-private partnerships in health care services: Do they outperform public hospitals regarding quality and access? Evidence from Portugal. Socio-Economic Planning Sciences. https://doi.org/10.1016/j.seps.2020.100798

Hodge, G., Greve, C., \& Boardman, A. (2017). Public-Private Partnerships: The Way They Were and What They Can Become. Infrastructure Public-Private Partnership: Australian Journal of Public Administration, 76(3), 273-282. doi: 10.1111/1467-8500.12260.

Kraevoy, S.A. (2019). Chastnye investitsii dlya razvitiya meditsiny [Private investment for the development of medicine]. Sovremennye strakhovye tekhnologii [Modern insurance technologies], (5), 8-11. Retrieved May 19, 2020, from https://www.consult-cct.ru/ upload/files/auto-pdflink/8-46511-6282.pdf (In Russ.)

Matos, N.B., \& Gonçalves, A.O. (2020). Public-private partnerships: origin, limitations and prospects for public sector accounting. REAd. Revista Eletronica de Administracao, 26(1), 114-136. doi: 10.1590/1413-2311.279.98525.

Ministry of Economic Development of the Chelyabinsk region. (2018). PPP in the field of healthcare: the problems of MHI and the choice of payment mechanism. Retrieved June 14, 2020, from https://mineconom74.ru/sites/default/files/imceFiles/user-318/no_ 3_-_08.11.2018_suhov_damir_gchp_v_sfere_zdravoohraneniya.pdf (In Russ.)

Molchanova, M.Y. (2016). Public-Privat e-Partnership in the System of Regional Healthcare Financing. Economic and Social Changes: Facts, Trends, Forecast, 44(2), 114-132. doi: 10.15838/esc.2016.2.44.7. (In Russ.)

Palcic, D., Reeves, E., Flannery, D., \& Geddes, R.R. (2019). Public-private partnership tendering periods: an international comparative analysis. Journal of Economic Policy Reform. doi: 10.1080/17487870.2019.1657016.

Sehgal, R., \& Dubey, A.M. (2019). Identification of critical success factors for public-private partnership projects. Journal of Public Affairs, 19(4), e1956. https://doi.org/10.1002/pa.1956

Sresakoolchai, J., \& Kaewunruen, S. (in press). Comparative studies into public private partnership and traditional investment approaches on the high-speed rail project linking 3 airports in Thailand. Transportation Research Interdisciplinary Perspectives, 5. https://doi.org/ 10.1016/j.trip.2020.100116

Stukalova, I.B., \& Provalenova, N.V. (2018). Foreign experience of development of the market of housing and communal services on the basis of state-private partnership. Bulletin NGIEI, 80(1), 76-88. (In Russ.)

World Bank Group. PPI Visualization Dashboard. Retrieved June 17, 2020, from https://ppi. worldbank.org/en/visualization\#sector $=\&$ status $=\& p p i=\&$ investment $=\circledR i$ ion $=\& i d a=\& i n c$ ome $=\& p p p=P P P \& m d b=\&$ year $=\&$ excel $=$ false $\&$ map $=\mathrm{CN} \&$ header $=$ true

Zavyalova, E.B., \& Tkachenko, M.V. (2018). The prospects and tasks of implementing public-private partnership in the social sector. RUDN Journal of Economics, 26(1), 61-75. https://doi.org/10.22363/2313-2329-2018-26-1-61-75 (In Russ.)

\section{Article history:}

Received: 25 April 2020

Revised: 20 May 2020

Accepted: 15 June 2020

\section{For citation:}

Lazanyuk, I.V., \& Yakovleva, T.V. (2020). Foreign experience in the implementation of PPP projects for the improvement of the Russian model. RUDN Journal of Economics, 28(3), 608-619. http://dx.doi.org/10.22363/2313-2329-2020-28-3-608-619

\section{Bio notes:}

Inna V. Lazanyuk, Associate Professor of the Department of Economic and Mathematical Modeling of the Faculty of Economics of the Peoples' Friendship University of Russia 
(RUDN University). eLIBRARY SPIN-code: 5482-3907, Scopus Author ID: 57214988996; ORCID ID: https://orcid.org/0000-0002-1834-3154. E-mail: lazanyuk-iv@rudn.ru

Tatiana V. Yakovleva, master of the Department of Economic and Mathematical Modeling of the Faculty of Economics of the Peoples' Friendship University of Russia (RUDN University). E-mail: tyakovleva009@gmail.com

DOI 10.22363/2313-2329-2020-28-3-608-619

Научная статья

\title{
Возможности применения зарубежного опыта реализации ГЧП-проектов для совершенствования отечественной модели
}

\author{
И.В. Лазанюк, Т.В. Яковлева \\ Российский университет дружбы народов \\ Российская Федеращия, 117198, Москва, ул. Миклухо-Маклая, 6
}

\begin{abstract}
Аннотация. В статье представлен комплексный анализ реализации зарубежных проектов ГЧП. Цель исследования состоит в выявлении особенностей реализации зарубежных ГЧП-проектов для совершенствования российского механизма, что предполагает решение определенных задач, а именно сравнения выбранных стран по критериям нормативно-правового обеспечения реализации ГЧП, используемых форм ГЧП, организационно-правовой структуры управления данными проектами. Прослежена зависимость приоритетности конкретных отраслей для реализации ГЧП от социально-экономического развития стран. Кроме того, выявлены проблемы в российской модели ГЧП и представлены пути их устранения на основе лучших зарубежных практик как для механизма в целом, так и применительно к конкретной сфере - здравоохранению.
\end{abstract}

Ключевые слова: ГЧП, государственно-частное партнерство, концессия, здравоохранение, бизнес, инфраструктура

\section{История статьи:}

Дата поступления в редакцию: 25 апреля 2020 г.

Дата проверки: 20 мая 2020 г.

Дата принятия к печати: 15 июня 2020 г.

\section{Для цитирования:}

Lazanyuk I.V., Yakovleva T.V. Foreign experience in the implementation of PPP projects for the improvement of the Russian model // Вестник Российского университета дружбы народов. Серия: Экономика. 2020. Т. 28. № 3. С. 608-619. http://dx.doi.org/10.22363/ 2313-2329-2020-28-3-608-619

\section{Сведения об авторах:}

Лазанюк Инна Васильевна, кандидат экономических наук, доцент кафедры экономикоматематического моделирования экономического факультета Российского университета дружбы народов. eLIBRARY SPIN-код: 5482-3907, Scopus Author ID: 57214988996, ORCID ID: https://orcid.org/0000-0002-1834-3154. E-mail: lazanyuk-iv@rudn.ru

Яковлева Татьяна Вадимовна, магистр кафедры экономико-математического моделирования экономического факультета Российского университета дружбы народов. E-mail: tyakovleva009@gmail.com 